\title{
INFLUENCE OF LAND USE ON THE INTEGRITY OF MARSH BIRD COMMUNITIES OF CHESAPEAKE BAY, USA
}

\author{
William V. DeLuca ${ }^{1}$, Colin E. Studds ${ }^{1}$, Larry L. Rockwood ${ }^{2}$, and Peter P. Marra ${ }^{1}$ \\ ${ }^{1}$ Smithsonian Environmental Research Center \\ Edgewater, Maryland, USA 21037-0028 \\ E-mail: delucaw@si.edu \\ ${ }^{2}$ Department of Environmental Science and Policy \\ George Mason University \\ Fairfax, Virginia, USA 22030
}

\begin{abstract}
The landscape within the Chesapeake Bay watershed has been and continues to be impacted by human modifications. Understanding if such anthropogenic disturbances influence organisms that are dependent upon estuarine wetlands remains unclear. We developed an index of marsh bird community integrity (IMBCI) to evaluate marsh bird communities and wetland condition. During the 2002 and 2003 summers, we detected 30 bird species at 219 point count locations distributed among 96 wetlands. IMBCI scores for each wetland were used to determine whether wetland habitat characteristics and urban/suburban development, agriculture, and forest at three different spatial scales (watershed, 1000-m buffer, and 500-m buffer) influenced marsh bird community integrity. We found no relationship between IMBCI scores and wetland habitat characteristics, implying that marsh bird community integrity is not related to any single plant community. Nonparametric changepoint analysis indicated that marsh bird community integrity was significantly reduced when the amount of urban/suburban development within $500 \mathrm{~m}$ and $1000 \mathrm{~m}$ of the marsh exceeded $14 \%$ and $25 \%$, respectively. There was no effect of urban/suburban development on IMBCI scores at the watershed scale. The results of our study demonstrate that marsh bird community integrity shows a threshold response to urban/suburban development at local scales. IMBCI scores, combined with the identification of a land-use threshold, can be easy to interpret and may help communicate complex ecological data to natural resource managers and conservation planners.
\end{abstract}

Key Words: threshold response, specialist, generalist, index of marsh bird community integrity, estuarine wetlands, Chesapeake Bay

\section{INTRODUCTION}

Virtually half of the world's population resides within $200 \mathrm{~km}$ of a coastline (Cohen et al. 1997). Between 1960 and 1990, the population of U.S. coastal areas increased by $41 \%$, with the Chesapeake Bay watershed having the fastest growing population in North America (Culliton et al. 1990). Accompanying these population increases are numerous anthropogenic landscape modifications, including expansion of urban/ suburban development. The cumulative result of these pressures is that the world's coastal ecosystems, including the Chesapeake Bay estuary, have become degraded (Nordstrom and Roman 1996, Edgar et al. 2000).

The increase in anthropogenic stressors in coastal areas makes it imperative to devise sound methods for assessing estuarine integrity and provide direction for future conservation efforts. Methods have already been developed for measuring the integrity of many components of estuarine systems, such as water quality, sediment quality, and the benthic community (Weisberg et al. 1997, Schimmel et al. 1999, Dauer et al. 2000). Methods for assessing estuarine wetland integrity, however, remain elusive largely due to dynamic environmental conditions, such as fluctuations in tidal cycles, salinity, and dissolved oxygen levels. Additionally, marsh ecosystems are particularly challenging to assess because they are vulnerable to a suite of landscape variables originating from surrounding areas and/or entire watersheds (Pennings et al. 2002).

One approach that could provide insight on estuarine wetland condition may be an index capable of measuring wetland community integrity. Thus far, most indices have focused on benthic and fish communities in freshwater (Angermeier and Karr 1986, Weisberg et al. 1997), marine (Dauer et al. 2000), and wetland ecosystems (Burton et al. 1999). The success of this technique in aquatic ecosystems has led to its expansion for use in other ecosystems. For example, avian indices have now been developed for forests 
(O'Connell et al. 1998, Canterbury et al. 2000), riparian areas (Bryce et al. 2002), and rangelands (Bradford et al. 1998).

An effective community index should reveal a signal of integrity and indicate the presence of a disturbance (Karr 1991). A community with high integrity is composed of species with attributes that are dependent upon components of an undisturbed system (O'Connell 2000). Such attributes are specialized and are typically sensitive to anthropogenic disturbance, while life history traits that are more generalized enable a species to use a variety of habitats. It is important to consider multiple life history attributes because it is possible for one species to have both specialist and generalist attributes (Price 1984). For example, red-winged blackbirds establish breeding territories only in wetland habitats, a fairly specialized attribute. In contrast, the foraging behavior of red-winged blackbirds can be characterized as a generalized attribute because they feed in marshes, garbage dumps, prairies, agricultural fields, and lawns (Yasukawa and Searcy 1995). By classifying the attributes of each species for the entire community on a specialist-to-generalist gradient, an index can be constructed that represents the integrity of that community.

Birds are considered ideal for use in a community index because they are easy to survey and avian life histories are relatively well defined. Previous research has shown that birds are linked to the overall ecological integrity of their respective ecosystem (Bradford et al. 1998, O'Connell 1998, Canterbury et al. 2000, Bryce et al. 2002). This is true primarily because they are sensitive to habitat fragmentation (Freemark and Collins 1992), landscape composition (Rodewald and Yahner 2001), and change in habitat structure (Riffell et al. 2001). Birds may also be particularly good indicators because species at high trophic levels can be sensitive to disturbances at lower levels (Pettersson et al. 1995). Therefore, it is unlikely that a marsh with low ecological integrity can support a high-integrity marsh bird community. Furthermore, a marsh that has a degraded upper trophic level (i.e., birds) cannot be considered to have high overall integrity.

We constructed a community index based on marsh birds designed to estimate the integrity of the marsh bird community and provide insight into the integrity of the entire marsh ecosystem. Previous IBIs have used sites that occur along a known reference to degradaded continuum to test potential metrics. Environmental stressors to estuarine wetlands remain relatively undescribed (Pennings et al. 2002). Therefore, identifying marshes on an a priori basis as either pristine or degraded can be problematic. We used sound ecological principles to develop an index of marsh bird community integrity (IMBCI) and subsequently tested the sensitivity of marsh bird community integrity to independently quantified land-use disturbances. Specifically, we scored marsh bird species attributes along a generalist-to-specialist gradient to develop species scores and, ultimately, site scores. Site scores were then used to determine whether wetland habitat characteristics and urban/suburban development, agriculture, and forest at three different geographic scales (watershed, 1000-m buffer, and 500-m buffer) affected marsh bird community integrity.

\section{METHODS}

Study Area

Our study was conducted in tidal wetlands of Chesapeake Bay, USA (39E 23' N; 36E 48' $\mathrm{N}$ to $76 \mathrm{E} 45^{\prime}$

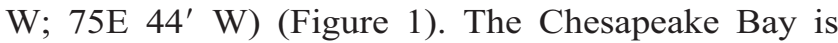
one of the largest and most productive estuaries in the world. It is characterized by 7,400 kilometers of tidal shoreline (Lippson and Lippson 1997), shallow waters, approximately 101,000 hectares of estuarine wetlands (Tiner and Burke 1995), and diverse floral and faunal communities. Land use within the Chesapeake Bay watershed is diverse. Industrial and high-density urban development is concentrated on the western shore of the bay near Baltimore, Maryland and Portsmouth, Virginia. Other areas of the western shore of the bay are primarily composed of oak-tulip poplar forests, urban/suburban development, and low-density agriculture. Commercial agriculture dominates the eastern shore of the bay and consists of row crops, chicken farms, and pasture.

Wetlands in the northern part of the bay are slightly more influenced by freshwater and have habitats characterized by narrow-leaved cattail (Typha angustifolia L.), common reed (Phragmites australis (Gav.) Trin.), arrow arum (Peltandra virginica L.), and rose mallow (Hibiscus moscheutos L.). Wetlands in the southern part of the bay are more saline and are dominated by smooth cordgrass (Spartina alterniflora Loisel.), salt meadow grass (Spartina patens (Ait.) Muhl.), big cordgrass (Spartina cynosuroides (L.) Roth), and marsh elder (Iva fructescens L.).

\section{Site Selection and Classification}

To include a full range of land-use types represented at multiple scales, we began by identifying five watershed categories across a land-use disturbance gradient. These watershed categories were used solely during site selection. We selected 30 watersheds of third through fifth order tributaries of the Chesapeake Bay distributed roughly evenly among five categories (see Table 1 for watershed land use composition): 1) 


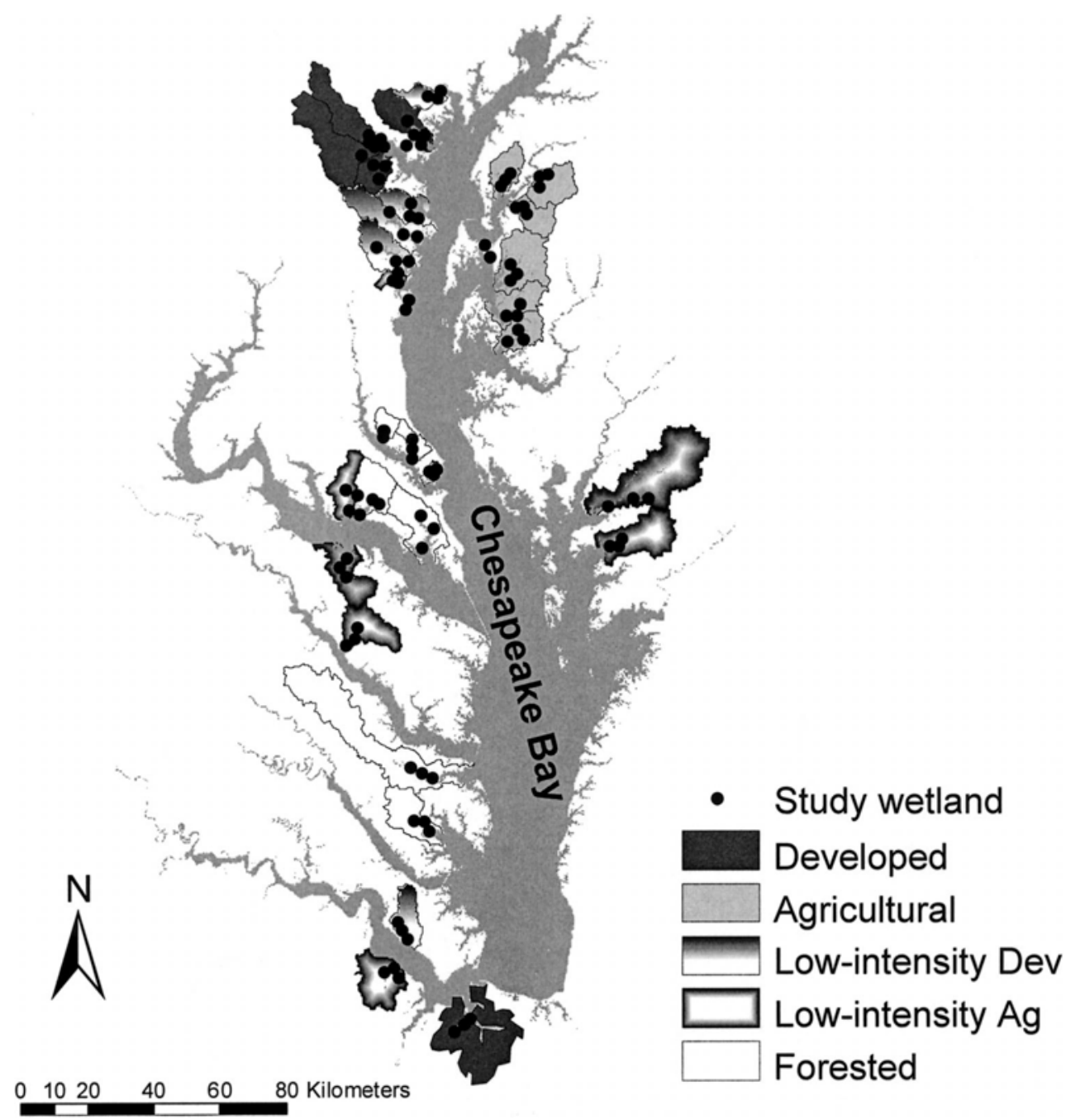

Figure 1. Map of Chesapeake Bay, USA showing the distribution and land-use classification of the 30 watersheds used in our study. All watersheds are associated with a sub-estuary, each of which contains three study wetlands.

urban/suburban development (hereafter, development); 2) low intensity development; 3) agriculture; 4) lowintensity agriculture; and 5) forested. Landscape composition was measured using National Land Cover Database (30-m raster coverage) and geographic information systems (GIS) software ArcGIS and ArcView (Environmental Systems Research Institute, Redlands, California).

Three estuarine wetlands were chosen as study sites within each watersheds' subestuary. A subestuary is a smaller estuarine embayment within a larger estuary (e.g., the Severn River within the Chesapeake Bay). Six wetlands were selected outside of the original 30 watersheds, resulting in 96 study sites. These additional six wetlands were selected due to a lack of large wetlands with extensive local development and were therefore included only in local land-use analysis. Buffers were developed using GIS at $1000 \mathrm{~m}$ and 500

Table 1. Percent of urban development, agriculture, and forest within each watershed category used during site selection (mean \pm standard deviation (range)).

\begin{tabular}{lccc}
\hline \multicolumn{1}{c}{ Watershed Category } & Urban Development & Agriculture & Forest \\
\hline Developed & $65.7 \pm 5.1(60.2-73.9)$ & $8.0 \pm 4.7(3.3-14.6)$ & $20.0 \pm 1.9(18.2-22.1)$ \\
Low-intensity development & $23.8 \pm 7.7(13.0-32.1)$ & $15.8 \pm 7.7(7.7-27.4)$ & $53.8 \pm 13.0(32.2-71.9)$ \\
Agriculture & $4.1 \pm 4.5(0.8-11.4)$ & $62.4 \pm 9.4(72.1-50.6)$ & $31.1 \pm 5.1(32.2-71.9)$ \\
Low-intensity agriculture & $4.1 \pm 3.3(0.7-8.6)$ & $35.7 \pm 4.0(31.2-40.3)$ & $53.6 \pm 6.1(32.2-71.9)$ \\
Forest & $4.2 \pm 2.5(1.0-7.4)$ & $20.6 \pm 4.9(16.0-29.0)$ & $72.8 \pm 6.1(32.2-71.9)$ \\
\hline
\end{tabular}


$\mathrm{m}$ and were exclusive for each study wetland. Landuse composition was calculated at each scale.

\section{Bird Community Sampling}

We used 50-m radius, five-minute, double observer point counts (Nichols et al. 2000) to sample the wetland bird community. Differences in species detectability were not calculated because the IMBCI is based on occurrence and estimates of abundance were not needed. One point count location was used to sample wetlands $<2$ ha, two for wetlands between 2 and 7 ha, and three for wetlands $>7$ ha. Point count locations were selected to encompass representative portions of the marsh and were $>150 \mathrm{~m}$ from the nearest point count and $>50 \mathrm{~m}$ from the upland edge. Two counts were conducted at each site from 15 May to 18 July between 0600 and 1100 hours, with a minimum of 14 days between counts. Fifty-seven wetlands were sampled in 2002, 66 wetlands were sampled in 2003, and 27 wetlands were sampled in both years.

At each wetland, a centrally located point count was selected to conduct an unlimited radius secretive marsh bird survey. At the conclusion of the point count, calls of black rail (Laterallus jamaicensis), least bittern (Ixobrychus exilis), common moorhen (Gallinula chloropus), Virginia rail (Rallus limicola), clapper rail (Rallus longirostris), sora (Porzana carolina), American bittern (Botaurus lentiginosus), and pied-billed grebe (Podilymbus podiceps) (obtained from Elliot et al. 1997) were broadcast. Species' calls were arranged from least intrusive to most intrusive (as listed above). Each playback period had one minute of a species' call, with a 30-second listening period between each species' call, and ended with a one-minute listening period as recommended by Gibbs and Melvin (1993) and Ribic et al. (1999).

\section{Wetland Habitat Measurements}

To quantify plant species composition and vegetation structure at each site, four vegetation sampling circles were established within each $50-\mathrm{m}$ radius $(0.79$ ha) point count location. Vegetation circles were $12 \mathrm{~m}$ in diameter, and the first circle was centered on the point count area. The remaining three circles were 35 $\mathrm{m}$ from the point count center at $0^{\circ}, 120^{\circ}$, and $240^{\circ}$, respectively. Each vegetation circle was divided into four equal quadrants. Within each quadrant, plant species' abundance was quantified using a modified Braun-Blanquet scale (Leps and Hadincova 1992). Percent cover values for each plant species were averaged among the four quadrants of each circle, then averaged again among the four circles, resulting in a percent cover value for each plant species for each point count location.

Vegetation structure was measured five meters from the center of each vegetation circle on each of the lines separating the four quadrants. Vertical structure was measured using methods modified from Haukos et al. (1998). A profile board (three meter pole with $0.1 \mathrm{~m}$ marked intervals) was held vertically while an observer, standing four meters away, determined the lowest $0.1 \mathrm{~m}$ increment not completely covered by vegetation. Horizontal structure was measured using similar methods; however, the profile board was held horizontally at $0.5 \mathrm{~m}, 1.0 \mathrm{~m}, 1.5 \mathrm{~m}$, and $2.0 \mathrm{~m}$ above the ground and an observer counted the number of $0.1 \mathrm{~m}$ sections not covered by vegetation at each height increment. Vegetation structure measurements for the entire point count circle were summarized using the same procedure as for percent cover values.

\section{Index of Marsh Bird Community Integrity}

The IMBCI developed in our study combined two approaches for developing indices of bird community integrity: 1) the guild-based community index (Croonquist and Brooks 1991, Weller 1995, Canterbury et al. 2000, O'Connell et al. 2000, Bryce et al. 2002), and 2) the indicator species approach (Landres et al. 1988, Pendergast and Eversham 1997, Tardif and DesGranges 1998, Chase et al. 2000). The IMBCI incorporates components of the guild-based community index by measuring species' attributes on a specialistto-generalist gradient. Specialists have attributes that are capable of exploiting specific resources of their native ecosystem. If those resources are disturbed, specialists are less capable of switching to other resources and are therefore a good indicator of habitat quality (Odum 1971, Miller et al. 1998, O’Connell et al. 2000). The IMBCI also examines the community at the species level and exploits the efficiency of including indicator species. The indicator species approach is capable of accurately linking a single species to a specific portion of an ecosystem (Kushlan 1979). Thus connections might be made that aid in the identification of a specific stressor to marsh condition. Combining components of both the guild and indicator species approaches, allows the IMBCI to be an accurate and sensitive index for a marsh bird community that has a low number of native species.

For the purpose of our study, we defined the term species' attribute as a component of a species' behavioral strategy or an inherent adaptation that a species uses for survival. Species' attributes were used as the basic component of IMBCI development. To represent the major factors that determine a species' vulnerability to disturbance, we used species' attributes that de- 
Table 2. Bird species attributes (Poole and Gill 1999) and scoring criteria used to develop Index of Marsh Bird Community Integrity (IMBCI) scores.

\begin{tabular}{|c|c|c|c|c|c|}
\hline \multirow[b]{3}{*}{$\begin{array}{l}\text { Species } \\
\text { attributes }\end{array}$} & \multicolumn{5}{|c|}{ Score } \\
\hline & Generalist & & 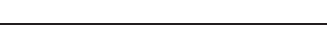 & $\longrightarrow$ & Specialist \\
\hline & 1 & 2 & 2.5 & 3 & 4 \\
\hline Foraging habitat & habitat generalist & & marsh facultative & & marsh obligate \\
\hline Nesting substrate & non-marsh nesters & & marsh vegetation & & marsh ground nester \\
\hline Migratory status & resident & & short distance/temperate & & Neotropical \\
\hline Breeding range & North America & $\begin{array}{l}\text { North America- } \\
\text { east of Rocky } \\
\text { Mts. }\end{array}$ & & $\begin{array}{l}\text { coastal North } \\
\text { America }\end{array}$ & $\begin{array}{l}\text { North America-east } \\
\text { coast only }\end{array}$ \\
\hline
\end{tabular}

scribed foraging, nesting, migration, and breeding range (Table 2). The presence of specialized bird foraging and nesting strategies in an ecosystem are representative of an undisturbed system (Canterbury et al. 2000, Bryce et al. 2002). The specialization of a species' migratory behavior was selected as a species' attribute in IMBCI development because it has been shown to respond as an indicator of disturbance (Croonquist and Brooks 1991, O’Connell 2000, Bryce et al. 2002). Breeding range was selected because it is likely that a bird with a limited range is adapted to conditions that are specific to that geographic region; thus, by measuring this attribute, we capture a species' capacity to respond to regional disturbances. For example, if coastal song sparrow (Melospiza melodia) populations are impacted by anthropogenic disturbances specific to coastal areas, the species may persist due to populations located inland. In contrast, the entire seaside sparrow (Ammodramus maritimus) population could be threatened because its range is confined to coastal areas.

To develop IMBCI scores, we first calculated the individual score for each species detected at a site $\left(\mathrm{S}_{\mathrm{IMBCI}}\right)$ :

$$
\mathrm{S}_{\mathrm{IMBCI}}=\sum \mathrm{L}_{\mathrm{S}}
$$

where $L_{S}$ is the score of each species' attribute on a scale of 1 to 4 (Table 1). Once all species' scores were calculated (Appendix I), scores for specific wetlands $\left(\mathrm{W}_{\mathrm{IMBCI}}\right)$ and sub-estuaries $\left(\mathrm{E}_{\mathrm{IMBCI}}\right)$ were calculated:

$$
\begin{aligned}
\mathrm{W}_{\text {IMBCI }} & =\left[\left(\sum \mathrm{S}_{\mathrm{IMBCI}} / \mathrm{S}_{\mathrm{N}}\right)+\mathrm{MO}_{\mathrm{N}}\right]-4 \\
\mathrm{E}_{\mathrm{IMBCI}} & =\sum \mathrm{W}_{\mathrm{IMBCI}} / \mathrm{M}_{\mathrm{N}}
\end{aligned}
$$

where $S_{N}$ is the total number of species detected at a wetland and $\mathrm{MO}_{\mathrm{N}}$ is the number of marsh obligate species detected at the wetland. The equation for $\mathrm{W}_{\text {IMBCI }}$ represents the mean species score for all species present, plus the total number of marsh obligate species at a wetland. These equations incorporate species at- tributes and species richness, while preserving a signal in the equation for what may be the most sensitive group to disturbance, marsh obligates. We subtract four while determining the $\mathrm{W}_{\text {IMBCI }}$ score to ensure a scoring scale that begins with zero and remains constant. $\mathrm{M}_{\mathrm{N}}$ is the total number of marshes sampled in a sub-estuary. Therefore, $\mathrm{E}_{\mathrm{IMBCI}}$ represents the mean score for all marshes sampled within a sub-estuary.

An IMBCI score of zero indicated that only species with generalist attributes were present (i.e., European Starling). An unweighted score of 12 indicated that all birds detected have specialist attributes that best indicate a healthy marsh ecosystem.

\section{Statistical Analyses}

A species was considered present at a wetland and given an IMBCI species score $\left(\mathrm{S}_{\mathrm{IMBCI}}\right)$ if it was detected at least once at any of the wetland's point count stations during either of the two surveys. Five sites contained no birds and, because IMBCI scores could not be calculated for sites without birds, these sites were not included in further analyses. Each wetland was considered an independent sample $(\mathrm{N}=96)$ when analyzing relationships between bird indices, wetland habitat characteristics, and landscape composition at the $500-\mathrm{m}$ and $1000-\mathrm{m}$ scales. Each $\mathrm{E}_{\mathrm{IMBCI}}$ score was considered an independent sample for watershed-level analysis $(\mathrm{N}=30)$.

We examined potential confounding variables to isolate the relationship between land use, habitat characteristics, and IMBCI scores. Regression analysis was performed on a sample of 52 sites to determine if salinity had an impact on the IMBCI. Study wetlands ranged in size from 0.01 to 130 hectares, and a regression analysis was used to determine if marsh patch size influenced IMBCI scores. There are were few large wetlands ( $>80 \mathrm{ha}$ ) associated with a defined watershed and within a subestuary in the Chesapeake Bay; consequently, our study included only three. To 
Table 3. Interpretation of axes from a principal component analysis of five vegetation structural measurements and 13 vegetation ground cover variables.

\begin{tabular}{lccc}
\hline Axis & $\begin{array}{c}\text { Cumulative percent } \\
\text { variance explained }\end{array}$ & $\begin{array}{c}\text { Eigen } \\
\text { values }\end{array}$ & Biological interpretation of axes \\
\hline PC 1 & 33.1 & 6.0 & $\begin{array}{c}\text { abundance of Phragmites australis, high vertical structure and dense, homo- } \\
\text { geneous horizontal structure } \\
\text { abundance of Hibiscus moscheutos, Peltandra virginica, and Typha angusti- } \\
\text { PClia, a marsh plant community indicative of lower salinity levels } \\
\text { abundance of Spartina patens, Distichlis spicata, and Iva fructescens, a } \\
\text { marsh plant community with generally higher salinity levels }\end{array}$ \\
PC 3 & 45.5 & 2.2 & $\begin{array}{c}\text { high cover values for bare ground and Amaranthus cannabinus, marshes ex- } \\
\text { hibiting characteristics of erosion }\end{array}$ \\
\hline
\end{tabular}

be certain that these sites would not produce a spurious correlation between IMBCI scores and wetland size, we used Cook's distance to measure whether regression coefficients would change if individual wetlands were removed from the analysis. None of the individual wetlands had an extreme influence on the relationship between IMBCI score and wetland size (Cook's distance $<1$ in all cases).

To determine if results from testing the IMBCI for area sensitivity were an artifact of passive sampling (Horn and Fletcher 2000, Johnson 2001), we randomly selected one point count from each marsh. Next, we included secretive marsh birds detected at the marsh, and then calculated the IMBCI score using only the randomly selected point. After confirming the effect of wetland size on IMBCI scores $(r=0.38, P<0.001)$, we used the standardized residuals of the analysis, which included all the point counts in a marsh as the dependent variable in subsequent analyses of IMBCI scores.

Upon exploring the relationship between IMBCI scores and land use at the watershed, 1000-m, and 500-m scales, it was evident that the data did not meet assumptions of linearity. Consequently, to test for a non-linear relationship, a non-parametric changepoint analysis (nCPA) (King and Richardson 2003, Qian et al. 2003) was used to test for the presence of an ecological threshold in the IMBCI due to percent development, agriculture, and forest at the three geographic scales. The nCPA detects changes in the mean and variance of an ecological response variable (in this case the IMBCI) due to changes of a disturbance (in this case land use at three geographic scales). It examines every point along a continuum of predictor values (e.g., percent development) and determines the probability that a value can split the data into two groups that have the highest between-group variance relative to within-group variance. The resulting cumulative probability curve illustrates the probability of a changepoint occurring at various levels of disturbance. When probabilities of a Type I error ( $P$ to be shown in Figure 3) were $<0.1$, we could be fairly certain that cumulative probability curves accurately assessed the likelihood of an ecological threshold occurring.

To analyze wetland habitat variables, a principal component analysis (PCA) was used to reduce the five vegetation structural measurements and the 13 groundcover variables that accounted for $80 \%$ of total ground cover to four principal components (Table 3) (Jongman et al. 1995). The standardized factor scores from each principal component for each site were then compared using multiple regression to determine if wetland habitat characteristics influenced IMBCI scores.

\section{RESULTS}

Wetlands averaged $3.51 \pm 0.23(\mathrm{SE})$ bird species per site, and thirty species were detected across all sites and used for IMBCI development and testing (Appendix I). The observed IMBCI scores for each wetland ranged from 1 to 10.39 , with a mean of $4.08 \pm 0.18$. Salinity did not have a significant effect on IMBCI scores $\left(\mathrm{r}^{2}=0.02, P=0.29\right)$. Wetland size had a significant influence on IMBCI scores (Figure 2). Consequently, the residuals from the analysis in Figure 2 were used to control for size in all subsequent analyses between IMBCI scores and land use.

\section{IMBCI and Land Use}

nCPA determined that development had a significant effect on IMBCI scores at the $500 \mathrm{~m}$ scale $(P=$ $0.04)$. The cumulative probability curve revealed a $95 \%$ chance of a changepoint occurring at $\leq 14 \%$ development (Figure 3). This result indicates that when $>14 \%$ of the area within $500 \mathrm{~m}$ of the marsh is developed, IMBCI scores change significantly. Furthermore, there was a relatively low probability $(25 \%)$ of a threshold response with $\leq 2 \%$ development. However, there was a $60 \%$ probability of a changepoint occurring when as little as $6 \%$ of the land within 500 


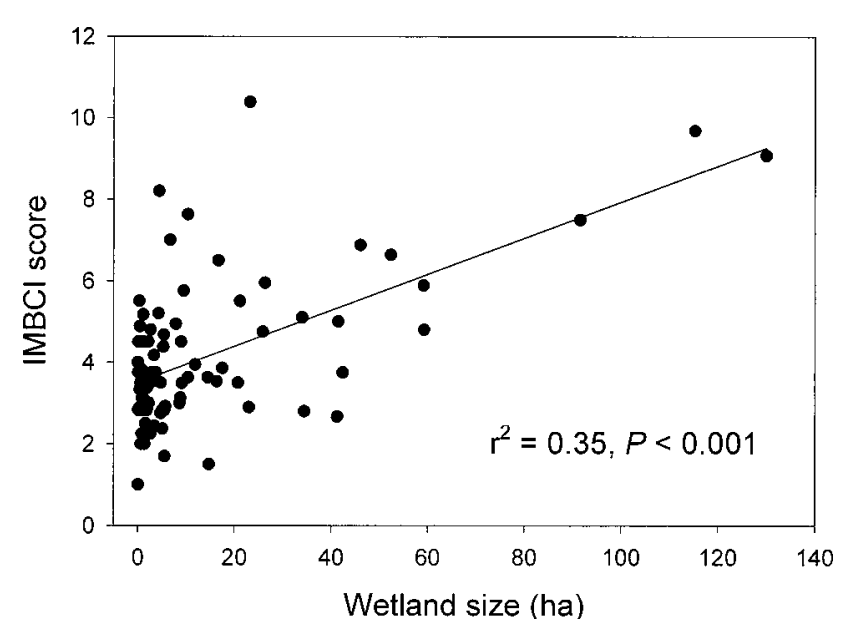

Figure 2. Results of a regression analysis showing the relationship between the index of marsh bird community integrity (IMBCI) and wetland size for 91 wetlands in the Chesapeake Bay, USA. IMBCI scores are calculated by scoring species attributes on a generalist to specialist gradient.

$\mathrm{m}$ of a wetland was developed (Figure 3). Changepoints were not detected when agriculture and forest were tested using nCPA against IMBCI scores at the $500 \mathrm{~m}$ scale $(P=0.22$ and $P=0.21$, respectively).

Development also had a significant effect on IMBCI scores at the $1000-\mathrm{m}$ buffer scale $(P=0.09)$. There was a $95 \%$ probability of a changepoint occurring at $\leq 25 \%$ development (Figure 3). At this scale, there was a $38 \%$ probability of a changepoint occurring with $\leq 2 \%$ development. Also, there was a $60 \%$ chance of a changepoint occurring when $\leq 8.5 \%$ of the $1000-\mathrm{m}$ buffer was developed (Figure 3). Changepoints were not detected for agriculture and forest at the 1000-m scale $(P=0.25, P=0.18$, respectively). We did not detect changepoints in IMBCI scores for percent development, agriculture, or forest at the watershed scale ( $P=0.22, P=0.22$, and $P=0.26$, respectively).

\section{IMBCI and Wetland Habitat Characteristics}

The PCA resulted in four axes that together explained $67.7 \%$ of the variation. Wetland plant communities (Table 2) did not have a significant effect on marsh bird community integrity $\left(\mathrm{r}^{2}=0.03\right.$, df $=90$, $P=0.74)$.

\section{DISCUSSION}

\section{IMBCI and Land Use}

An index of community integrity should be capable of measuring the response of a biological community to an environmental stressor (Bradford et al. 1998, O'Connell 2000). Our IMBCI identified thresholds

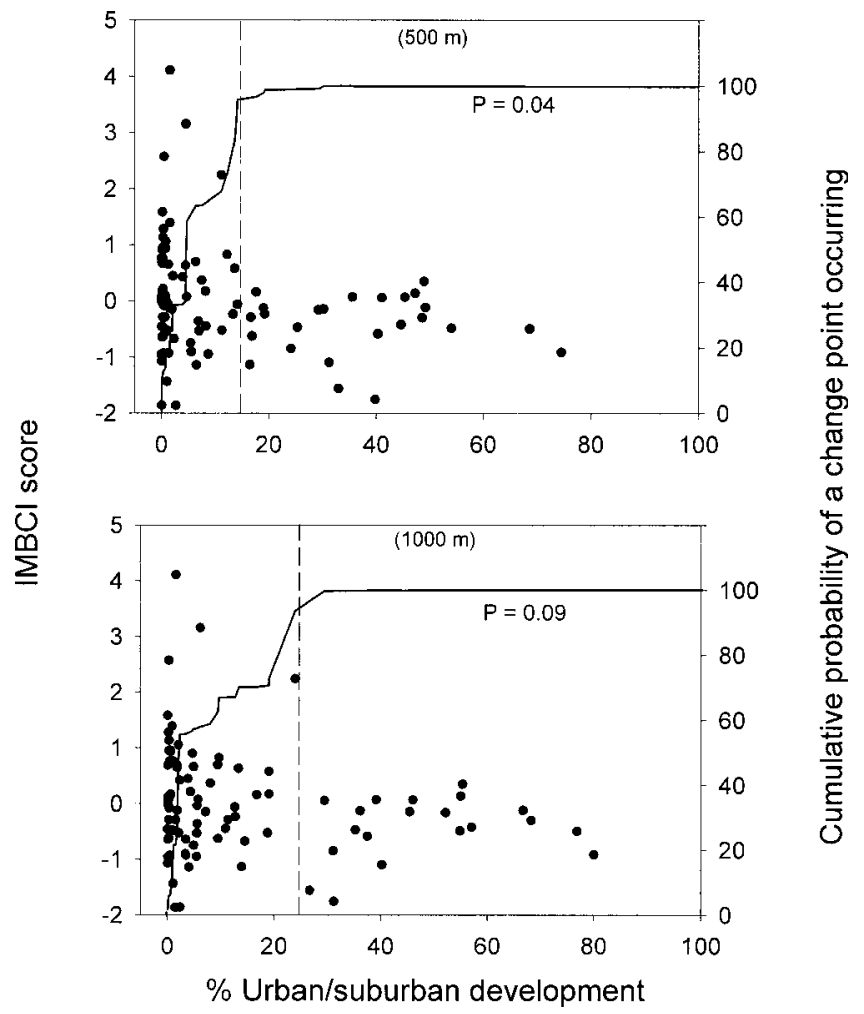

Figure 3. Results of non-parametric changepoint analyses for percent development within $500 \mathrm{~m}$ and $1000 \mathrm{~m}$ of wetland study sites and index of marsh bird community integrity (IMBCI) scores controlled for wetland size using the standardized residuals from Figure 2. The cumulative probability curve represents the cumulative probability that a changepoint occurred at various levels of development. IMBCI scores are calculated by scoring species' attributes on a generalist to specialist gradient. Dashed lines indicate the percent of development within a wetland buffer required to produce a $95 \%$ cumulative probability of an ecological threshold occurring.

with $95 \%$ probability for the amount of development that can occur within 500-m (14\%) and 1000-m (25\%) buffers of an estuarine wetland before ecological integrity is significantly compromised (Figure 3). Moreover, we found a $60 \%$ probability that a changepoint occurred in IMBCI scores with relatively low levels of disturbance $(6 \%$ development at the $500-\mathrm{m}$ scale and $8.5 \%$ development at the $1000-\mathrm{m}$ scale). The thresholds identified in our study indicate levels of local disturbance, beyond which, marsh bird community integrity is unattainable. This does not imply that marshes with local percent development levels below thresholds necessarily have high integrity. It does imply, however, that marshes with local development below threshold levels have the capacity for high integrity, whereas marshes with local development above threshold levels do not.

Other studies have also identified ecological thresh- 
olds or non-linear responses to anthropogenic disturbances. Interestingly, most reported thresholds were found between 10 and $20 \%$ disturbance, similar to the results of our study. For example, Paul and Meyer (2001) reported thresholds of stream degradation when impervious surface in stream catchments exceeded 10 to $20 \%$. Urban disturbance has also been linked to degradation of fish communities with as little as 10 (Limburg and Schmidt 1990) and 20\% (Wang et al. 1997) impervious surface area within stream catchments. These studies, in concert with our findings, provide strong evidence that the response of biological communities dependant upon various aquatic systems respond to anthropogenic disturbances in similar, nonlinear manners (i.e., threshold response).

Understanding the spatial scale at which land use influences the integrity of an ecosystem may provide some insight into the potential mechanisms driving the response. In our study, the threshold response to development decayed when we moved from local buffers to the watershed scale. This finding implies that there is a scale-dependent effect of development on estuarine wetlands. Findlay and Houlahan (1997) and Whited et al. (2000) both found that road density at local scales had a pronounced negative effect on wetland bird assemblages and concluded that reduced connectivity between wetland patches caused by development may have restricted wetland bird distribution. Disturbances in close proximity to wetlands also provides habitat for an abundance of generalist birds (Blair 1996). Generalists are then capable of invading the marsh and increasing interspecific competition with marsh birds for available resources.

Fragmented, isolated, and altered forest patches are known to be less suitable for terrestrial bird communities (Faaborg 1995). The primary mechanisms behind forest fragmentation and isolation effects may also apply to marsh bird communities. Small and Hunter (1988) found that roads, power lines, and edges, all characteristics of developed areas, provide pathways for potential predators to enter undisturbed habitat and depredate bird nests. Pathways or corridors such as these may act in similar ways near marshes to increase nest predation and lower reproductive success. Another explanation for the reduction in marsh bird community integrity may be the transfer of pollutants from adjacent land. Chemical pollutants and nutrients transferred from developed areas through point sources may reduce the food resources of marsh birds (Poulin et al. 2002). For example, aquatic macroinvertebrates might be impacted from such pointsource pollution. Interestingly, most secretive marsh birds, marsh foraging specialists, feed primarily on aquatic macroinvertebrates, and only three of the 45 lowest scoring wetland sites of our study had secretive marsh birds present. Future research aimed at identifying stressors may need to look at how the macroinvertebrate community is affected by changes in soil and water chemistry of a marsh.

\section{IMBCI and Wetland Habitat Characteristics}

Previous studies have shown that vegetation composition and structure can influence bird distribution and abundance in wetlands (Burger 1982, Craig and Beal 1992, Watts 1993, Reinert and Mello 1995, Riffell et al. 2001). Our study did not address this question directly, but instead examined how various attributes of wetland plant communities influenced marsh bird community integrity. We found that marsh bird community integrity was not dependent on any one marsh plant community type. This is not to say that the marsh plant community does not influence bird distribution. Rather, it implies that marsh bird communities may reach high integrity in a number of marsh plant communities. Such is the case when a specialist bird that inhabits one type of plant community is replaced by other specialists in different plant communities. For example, seaside sparrows and clapper rails that inhabit marshes dominated by Iva fructescens and Spartina alterniflora are replaced by marsh wrens and virginia rails in a marsh dominated by Typha angustifolia and Phragmites australis. Therefore, marsh plant communities may not be good predictors of marsh bird community integrity. Managers should use caution however, because it is uncertain how dramatic temporal changes in plant communities due to extreme hydrological changes (Wilcox et al. 2002) may influence the IMBCI. Our findings illustrate that although the IMBCI can accurately measure how specialized a bird community is, it is less useful for recognizing how marsh bird community composition varies among marshes of similar integrity.

\section{CONCLUSIONS}

Our research demonstrates that anthropogenic disturbance surrounding a wetland can have negative effects on marsh bird community integrity. Furthermore, we identified a specific land-use disturbance threshold at approximately $14 \%$, similar to thresholds identified in other studies. Such information, as provided by this and other research (Findlay and Houlahan 1997, Findlay and Bourdages 2000, Whited et al. 2000), should be incorporated into existing wetland assessments, which tend to include primarily within-site characteristics. Finally, our study has shown that marsh bird community integrity is not dependent on any one type of marsh plant community. Wetland managers should consider that marsh bird communities with high integ- 
rity may be found in a variety of wetland community types.

In summary, the IMBCI can be an accurate indicator of marsh bird community integrity that may assist in the assessment of the integrity of the entire marsh ecosystem. IMBCI scores, combined with the identification of a land-use threshold, are easily interpreted, and provide rapid assessment approaches for communicating complex ecological data to natural resource managers and conservation planners. By helping to bridge the gap between scientists and regional conservation decision makers, the IMBCI could become a valuable contribution to the ongoing efforts of restoring and maintaining the ecological integrity of the Chesapeake Bay. Finally, this approach could provide a template for measuring ecological integrity in other marsh systems in North America and potentially throughout the world.

\section{ACKNOWLEDGMENTS}

We appreciate the hard work of Anne Balogh, Suzanne Conrad, Sacha Mkheidze, Dan Mummert, Ryan Peters, and Beth Wright. We also thank Ryan King for providing statistical advice and improvements on the manuscript and Tim O'Connell for assistance during IMBCI development. This research was funded by a grant from the U.S. Environmental Protection Agency's Science to Achieve Results (STAR) Estuarine and Great Lakes (EaGLe) program to the Atlantic Slope Consortium. Although the research described in this article has been funded wholly or in part by the U.S. Environmental Protection Agency through cooperative agreement \#R-82868401 to the Smithsonian Environmental Research Center, it has not been subjected to the Agency's required peer and policy review and therefore does not necessarily reflect the views of the Agency and no official endorsement should be inferred.

\section{LITERATURE CITED}

Angermeier, P. L. and J. R. Karr. 1986. Applying an index of biotic integrity based on stream-fish communities: considerations in sampling and interpretation. North American Journal of Fisheries Management 6:418-429.

Blair, R. B. 1996. Land use and species diversity along an urban gradient. Ecological Applications 6:506-519.

Bradford, D. F., S. E. Franson, G. R. Miller, A. C. Neale, G. E. Canterbury, and D. T. Heggem. 1998. Bird species assemblages as indicators of biotic integrity in Great Basin rangeland. Environmental Monitoring and Assessment 49:1-22.

Bryce, S. A., R. M. Hughes, and P. R. Kaufmann. 2002. Development of a bird integrity index: using bird assemblages as indicators of riparian condition. Environmental Management 30:294310 .

Burger, J., J. Shisler, and F. H. Lesser. 1982. Avian utilization of six salt marshes in New Jersey. Biological Conservation 23:187212.
Burton, T. M., D. G. Uzarski, J. P. Gathman, J. A. Genet, B. E. Keas, and C. A. Stricker. 1999. Development of a preliminary invertebrate index of biotic integrity for Lake Huron costal wetlands. Wetlands 19:869-882.

Canterbury, G. E., T. E. Martin, D. R. Petit, L. J. Petit, and D. F. Bradford. 2000. Bird communities and habitat as ecological indicators of forest condition in regional monitoring. Conservation Biology 14:544-558.

Chase, M. K., W. B. Kristan III, A. J. Lynam, M. V. Price, and J. T. Rotenberry. 2000. Single species as indicators o species richness and composition in California coastal sage scrub birds and small mammals. Conservation Biology 14:474- 487.

Cohen, J. E., C. Small, A. Mellinger, J. Gallup, and J. Sachs. 1997. Estimates of coastal populations. Science 278:1211-1212.

Craig, R. J. and K. G. Beal. 1992. The influence of habitat variables on marsh bird communities of the Connecticut River estuary. Wilson Bulletin 104:295-311.

Croonquist, M. J. and R. P. Brooks. 1991. Use of avian and mammalian guilds as indicators of cumulative impacts in riparian wetland areas. Environmental Monitoring 15:701-714.

Culliton, T. J., M. A. Warren, T. R. Goodspeed, D. G. Remer, C. M. Blackwell, and J. J. McDonough, III. 1990. 50 Years of Population Change along the Nation's Coasts, 1960-2010. U.S. Department of Commerce, National Oceanic and Atmospheric Administration. Rockville, MD, USA.

Dauer, D. M., J. A. Ranasinghe, and S. B. Weisberg. 2000. Relationsships between benthic community condition, water quality, sediment quality, nutrient loads, and land use patterns in Chesapeake Bay. Estuaries 23:80-96.

Edgar, G. J., N. S. Barrett, D. J. Graddon, and P. R. Last. 2000. The conservation significance of estuaries: A classification of Tasmanian estuaries using ecological, physical and demographic attributes as a case study. Biological Conservation 92:282-397.

Elliot, L., D. Stokes, and L. Stokes. 1997. Stokes Field Guide to Bird Songs. Time Warner AudioBooks, New York, NY, USA.

Faaborg, J., M. Brittingham, T. Donovan, and J. Blake. 1995. Habitat fragmentation in the temperate zone. p. 357-380. In T. E. Martin and D. Finch (eds.) Ecology and Management of Neotropical Migratory Birds: a Synthesis and Review of Critical Issues. Oxford University Press, New York, NY, USA.

Findlay, C. S. and J. Houlahan. 1997. Anthropogenic correlates of species richness in southeastern Ontario wetlands. Conservation Biology 11:1000-1009.

Findlay, C. S. and J. Bourdages. 2000. Response time of wetland biodiversity to road constuction on adjacent lands. Conservation Biology 14:86-94.

Freemark, K. and B. Collins. 1992. Landscape ecology of birds breeding in temperate forest fragments. p. 443-454. In J. M. Hagan III and D. W. Johnston, (eds.) Ecology and Conservation of Neotropical Migrant Landbirds. Smithsonian Institution Press, Washington DC, USA.

Gibbs, J. P. and S. M. Melvin. 1993. Call-response surveys for monitoring breeding waterbirds. Journal of Wildlife Management 57: $27-34$.

Haukos, D. A., H. Z. Sun, D. B. Webster, and L. M. Smith. 1998. Sample size, power, and Analytical considerations for vertical structure data from profile boards in wetland vegetation. Wetlands 18:203-215.

Horn, D. J. and R. J. Fletcher, Jr. 2000. Detecting area sensitivity: A comment on previous studies. American Midland Naturalist 144:28-35

Johnson, D. H. 2001. Habitat fragmentation effects on birds in grasslands and wetlands: A critique of our knowledge. Great Plains Research 11:211-231.

Jongman, R. G. H., C. J. F. Ter Braak, and O. F. R. Van Tongeren, (eds.). 1995. Data Analysis in Community and Landscape Ecology. Cambridge University Press, New York, NY, USA.

Karr, J. R. 1991. Biological integrity: a long-neglected aspect of water resource management. Ecological Applications 1:66-84.

King, R. S. and C. J. Richardson. 2003. Integrating bioassessment and ecological risk assessment: an approach to developing numerical water-quality criteria. Environmental Management 31: 795-809. 
Kushlan, J. A. 1979. Design and management of continental wildlife reserves: Lessons from the Everglades. Biological Conservation 15:281-290.

Landres, P. B., J. Verner, J. W. Thomas. 1988. Ecological uses of vertabrate indicator species: A critique. Conservation Biology 2: 316-328.

Leps, J. and V. Hadincova. 1992. How reliable are our vegetation analysis? Journal of Vegetation Science 3:119-124.

Limburg, K. E. and R. E. Schmidt. 1990. Patterns of fish spawning in Hudson River tributaries: response to an urban gradient? Ecology $71: 1238-1245$

Lippson, A. J. and R. L. Lippson. 1997. Life in the Chesapeake Bay. The Johns Hopkins University Press. Baltimore, MD, USA.

Miller, S. G., R. L. Knight, and C. K. Miller. 1998. Influence of recreational trails on breeding bird communities. Ecological Applications 8:162-169.

Nichols, J. D., J. E. Hines, J. R. Sauer, F. W. Fallon, J. E. Fallon, and P. J. Heglund. 2000. A double-observer approach for estimating detection probability and abundance from point counts. The Auk 117:393-408.

Nordstrom, K. F. and C. T. Roman (eds.). 1996. Estuarine Shores. John Wiley and Sons Ltd, Chichester, England.

O'Connell, T. J., L. E. Jackson, and R. P. Brooks. 1998. A bird community index of biotic integrity for the Mid-Atlantic Highlands. Environmental Monitoring Assessment 51:145-156.

O'Connell, T. J., L. E. Jackson, and R. P. Brooks. 2000. Bird guilds as indicators of ecological condition in the central Appalachians. Ecological Applications 10:1706-1721.

Odum, E. P. 1971. Fundamentals of Ecology. $3^{\text {rd }}$ edition. W. B. Saunders, Philadelphia, PA, USA.

Paul, M. J. and J. L. Meyer. 2001. Streams in the urban landscape. Annual Review of Ecology and Systematics 32:333-365.

Pendergast, J. R. and B. C. Eversham. 1997. Species richness covariance in higher taxa: empirical tests of the biodiversity indicator concept. Ecography 20:210-216.

Pennings, S. C., V. D. Wall, D. J. Moore, M. Pattanayek, T. L. Buck, and J. J. Alberts. 2001. Assessing salt marsh health: a test of the utility of five potential indicators. Wetlands 22:405-414.

Pettersson, R. P., J. P. Ball, K. Renhorn, P. Esseen, and K. Sjoberg. 1995. Invertabrate communities in boreal forest canopies as influenced by forestry and lichens with implications for passerine birds. Biological Conservation 74:57-63.

Poole, A., and F. Gill. 1999. The Birds of North America. The Birds of North America, Inc., Philadelphia, PA, USA.

Poulin, B., G. Lefebvre, and A. Mauchamp. 2002. Habitat requirements of passerines and reedbed management in souther France. Biological Conservation 107:315-325.

Price, P. W. 1984. Communities of specialists: vacant niches in ecological and evolutionary time. p. 510-523. In D. R. Strong Jr., D. Simberloff, L. G. Abele, and A. B. Thistle, (eds.) Ecological Communities, Conceptual Issues and the Evidence. Princeton University Press, Princeton, NJ, USA.

Qian, S. S., R. S. King, and C. J. Richardson. 2003. Two statistical methods for the detection of environmental thresholds. Ecological Modelling 166:87-97.
Reinert, S. E. and M. J. Mello. 1995. Avian community structure and habitat use in a southern New England estuary. Wetlands 15: 9-19.

Ribic, C. A., S. J. Lewis, S. Melvin, J. Bart, and B. Peterjohn. 1999. Proceedings from the marsh bird monitoring workshop. U.S. Fish and Wildlife Service, U.S. Geological Survey, National Wildlife Visitor Center, Laurel, MD, USA.

Riffell, S. K., B. E. Keas, and T. M. Burton. 2001. Area and habitat relationships in Great Lakes coastal wet meadows. Wetlands 21: 492-507.

Rodewald, A. D. and R. H. Yahner. 2001. Influence of landscape composition on avian community structure and associated mechanisms. Ecology 82:3493-3504.

Schimmel, S. C., S. J. Benyi, and C. J. Strobel. 1999. An assessment of the ecological condition of Long Island Sound, 1990-1993. Environmental Monitoring and Assessment 56:27-49.

Small, M. F. and M. L. Hunter. 1988. Forest fragmentation and avian nest predation in forested landscapes. Oecologia 76:62-64.

Tardif, B. and J-L. DesGranges. 1998. Correspondance between bird and plant hotspots of the St. Lawrence River and the influence of scale on their location. Biological Conservation 84:53-63.

Tiner, R. W. and D. G. Burke. 1995. Wetlands of Maryland. U.S. Fish and Wildlife Service, Ecological Services, Region 5, Hadley, MA and Maryland Department of Natural Resources, Annapolis, MD. Cooperative publication 1-193.

Wang, L., J. Lyons, P. Kanehl, and R. Gatti. 1997. Influences of watershed land use on habitat quality and biotic integrity in Wisconsin streams. Fisheries 22:6-12.

Watts, B. D. 1993. Effects of marsh size on incidence rates and avian community organization within the lower Chesapeake Bay (Final report). Center for Conservation Biology, College of William and Mary:1-54.

Weisberg, S. B., J. A. Ranasingh, D. M. Dauer, L. C. Schaffner, R. J. Diaz, and J. B. Frithsen. 1997. An estuarine benthic index of biotic integrity (B-IBI) for Chesapeake Bay. Estuaries 20:149158.

Weller, M. W. 1995. Use of two waterbird guilds as evaluation tools for the Kissimmee River restoration. Restoration Ecology 3:211224.

Whited, D., S. Galatowitsch, J. R. Tester, K. Schik, R. Lehtinen, and J. Husveth. 2000. The importance of local and regional factors in predicting effective conservation planning strategies for wetland bird communities in agricultural and urban landscapes. Landscape and Urban Planning 49:49-65.

Wilcox, D. A., J. E. Meeker, P. L. Hudson, B. J. Armitage, M. G. Black, and D. G. Uzarski. 2002. Hydrologic variability and the application of index of biotic integrity metrics to wetlands: a Great Lakes evaluation. Wetlands 22:588-615.

Yasukawa, K. and W. A. Searcy. 1995. Red-winged Blackbird (Agelaius phoeniceus). p. 1-28. In A. Poole and F. Gill (eds.) The Birds of North America, No.184. The Birds of North America Inc., Philadelphia, PA, USA.

Manuscript received 23 December 2003; revisions received 28 June 2004; accepted 22 August 2004. 
Appendix I. List of bird species detected during point count surveys in Chesapeake Bay marshes, including scores for each species attribute used to calculate the total species score $\left(\mathrm{S}_{\mathrm{IMBCI}}\right)$ in IMBCI development.

\begin{tabular}{|c|c|c|c|c|c|c|}
\hline Common name & Scientific name & $\begin{array}{l}\text { Forag- } \\
\text { ing } \\
\text { habitat }\end{array}$ & $\begin{array}{c}\text { Nesting } \\
\text { sub- } \\
\text { strate }\end{array}$ & $\begin{array}{c}\text { Migra- } \\
\text { tory } \\
\text { status }\end{array}$ & $\begin{array}{l}\text { Breed- } \\
\text { ing } \\
\text { range }\end{array}$ & $\mathrm{S}_{\mathrm{IMBC}}$ \\
\hline Least bittern* & Ixbrychus exilis (Gmelin) & 4 & 2.5 & 4 & 1 & 11.5 \\
\hline Green heron* & Butorides virescens (L.) & 2.5 & 1 & 4 & 1 & 8.5 \\
\hline Clapper rail* & Rallus longirostris (Gmelin) & 4 & 4 & 2.5 & 3 & 13.5 \\
\hline Virginia rail* & Rallus limicola (Viellot) & 4 & 4 & 2.5 & 1 & 11.5 \\
\hline Willet* & Catoptrophorus semipalmatus (Gmelin) & 4 & 4 & 4 & 4 & 16 \\
\hline Chimney swift & Chaetura pelagica (L.) & 1 & 1 & 4 & 2 & 8 \\
\hline Ruby-throated hummingbird & Archilochus colubris (L.) & 1 & 1 & 4 & 2 & 8 \\
\hline Eastern kingbird & Tyrannus tyrannus (L.) & 2.5 & 1 & 4 & 1 & 8.5 \\
\hline American crow & Corvus brachyrhynchos (Brehm) & 1 & 1 & 1 & 1 & 4 \\
\hline Purple martin & Pronge subis (L.) & 1 & 1 & 4 & 1 & 7 \\
\hline Bank swallow & Riparia riparia $(\mathrm{L})$. & 1 & 1 & 4 & 1 & 7 \\
\hline Tree swallow & Tachycineta bicolor (Vieillot) & 1 & 1 & 4 & 1 & 7 \\
\hline Barn swallow & Hirundo rustica (L.) & 1 & 1 & 4 & 1 & 7 \\
\hline Marsh wren* & Cistothorus palustris (Wilson) & 4 & 2.5 & 2.5 & 1 & 10 \\
\hline American robin & Turdus migratorius (L.) & 1 & 1 & 1 & 1 & 4 \\
\hline Gray catbird & Dumetella carolinensis (L.) & 1 & 1 & 4 & 1 & 7 \\
\hline European starling & Sturnus vulgaris (L.) & 1 & 1 & 1 & 1 & 4 \\
\hline Yellow warbler & Dendroica petechia (L.) & 1 & 1 & 4 & 1 & 7 \\
\hline Common yellowthroat & Geothlypis trichas (L.) & 2.5 & 2.5 & 4 & 1 & 10 \\
\hline Indigo bunting & Passerina cyanea (L.) & 1 & 1 & 4 & 2 & 8 \\
\hline Chipping sparrow & Spizella passerina (Bechstein) & 1 & 1 & 1 & 1 & 4 \\
\hline Seaside sparrow* & Ammodramus maritimus (Wilson) & 4 & 2.5 & 2.5 & 4 & 13 \\
\hline Song sparrow & Melospiza melodia (Wilson) & 1 & 1 & 2.5 & 1 & 5.5 \\
\hline Swamp sparrow* & Melospiza Georgiana (Latham) & 4 & 2.5 & 2.5 & 4 & 13 \\
\hline Northern cardinal & Cardinalis cardinalis (L.) & 1 & 1 & 1 & 2 & 5 \\
\hline Brown-headed cowbird & Molothrus ater (Boddaert) & 1 & 1 & 1 & 1 & 4 \\
\hline Red-winged blackbird & Agelaius phoeniceus (L.) & 1 & 2.5 & 2.5 & 1 & 8.5 \\
\hline Common grackle & Quiscalus quiscula (L.) & 1 & 1 & 1 & 2 & 5 \\
\hline Boat-tailed grackle* & Quiscalus major (Vieillot) & 1 & 2.5 & 1 & 4 & 8.5 \\
\hline American goldfinch & Carduelis tristis (L.) & 1 & 1 & 1 & 1 & 4 \\
\hline
\end{tabular}

* Wetland obligates. 